\title{
PELAKSANAAN SUPERVISI AKADEMIK KEPALA MADRASAH DALAM MENINGKATKAN KINERJA GURU PADA MADRASAH IBTIDAIYAH SWASTA (MIS) SINGKARAK KABUPATEN SOLOK
}

\author{
Joni \\ Kepala MIN Kota Solok \\ Komplek Masijd Agung Al-Muhsinin Kota Solok \\ e-mail: jonigantri@yahoo.com.id
}

\begin{abstract}
This study aimed at describing the implementation of the headmaster's academic supervision on upgrading teachers' performance in Islamic Primary School Singkarak, Solok. The interview and documentation were used as insturments to collect data. The results revealed that the supervision was run well, the headmaster did usual supervision and clinical supervision on upgrading the teachers' performance.
\end{abstract}

Keywords: Headmaster, Supervision, Teachers' Performance, Islamic Primary School Singkarak, Solok.

\section{PENDAHULUAN}

Pendidikan bertujuan mencerdaskan kehidupan bangsa dan merupakan suatu proses untuk meningkatkan kualitas manusia Indonesia dalam mewujudkan masyarakat adil dan makmur. Diharapkan pendidikan mampu mengantarkan warga Indonesia mengembangkan dirinya dalam segala aspek kehidupan.

Dalam Undang-Undang 1945, salah satu tujuan Nasional yang ingin dicapai oleh bangsa Indonesia adalah mencerdaskan kehidupan bangsa. Bangsa yang berhasil adalah bangsa yang bisa memberikan kemajuan dalam bidang ilmu pengetahuan.
Salah satu upaya untuk memajukan ilmu pengetahuan adalah dengan cara memajukan pendidikan.

Pendidikan tidak pernah terpisah dari kehidupan manusia. Anak-anak menerima pendidikan dari orang tuanya dan manakala anak-anak sudah dewasa dan berkeluarga mereka juga akan mendidik anaknya, begitu pula di madrasah dan perguruan tinggi, siswa dan mahasiswa dididik oleh guru dan dosen (Pidarta, 2006).

Dalam dunia pendidikan, peranan guru sangatlah penting, yakni orang yang bertanggungjawab mencerdaskan kehidupan anak didik, dan bertanggungjawab atas segala 
sikap, tingkah laku dan perbuatan dalam rangka membina anak didik agar menjadi orang yang bersusila, cakap, dan berguna bagi nusa dan bangsa. Kinerja guru yang optimal merupakan dambaan setiap madrasah. Guru yang memiliki kinerja yang baik dapat dilihat dari berbagai performan yang ditampilkannya. Untuk melihat kinerja guru dapat dilihat dari kemampuan dalam menyiapkan perangkat pembelajaran, seperti pembuatan silabus, penyusunan RPP, menentukan dan memilih model, pendekatan, strategi dan metode pembelajaran, menggunakan media pembelajaran, menyusun perangkat tes dan penilaian yang semuanya itu dapat diimplementasikan dengan baik pada kegiatan pembelajaran.

Sulistiyoroni (2001) menyebutkan bahwa kinerja adalah tingkat keberhasilan seseorang atau kelompok orang dalam melaksanakan tugas dan tanggung jawabnya serta kemampuan untuk mencapai tujuan dan standar yang telah ditetapkan. Sedangkan menurut Timple (1992) bahwa kinerja merupakan hasil dari fungsi pekerjaan atau kegiatan tertentu yang di dalamnya terdiri dari tiga aspek yaitu kejelasan tugas atau pekerjaan yang menjadi tanggung jawabnya; kejelasan hasil yang diharapkan dari suatu pekerjaan atau fungsi; dan kejelasan waktu yang diperlukan untuk menyelesaikan suatu pekerjaan agar hasil yang diharapkan dapat terwujud.
Kinerja guru sangat penting untuk diperhatikan dan dievaluasi karena guru mengemban tugas professional, artinya tugas-tugas hanya dapat dikerjakan dengan kompetensi khusus yang diperoleh melalui program pendidikan. Danim (2002) mengungkapkan bahwa guru memiliki tanggung jawab yang secara garis besar dapat dikelompokkan yaitu (1) sebagai pengajar; (2) sebagai pembimbing; dan (3) sebagai administrator kelas.

Berbagai cara telah ditempuh oleh pemerintah dalam upaya peningkatan kualitas guru demi tercapai tingkat tamatan yang berkualitas yang nantinya akan mampu bersaing dalam pasar kerja Regional, Nasional, maupun Internasional. Salah satu upaya yang dilakukan oleh pemerintah adalah melalui sertifikasi guru, sehingga diharapkan kinerja guru akan meningkat dan profesional melaksanakan tugas mengajar.

Madrasah merupakan lembaga pendidikan yang berperan sebagai salah satu wakil dari pemerintah agar mencapai tujuan pendidikan Nasional. Dalam organisasi madrasah, kedudukan kepala madrasah merupakan faktor penentu dan penggerak dalam segala sumber daya yang ada di madrasah. Fungsi kepala madrasah adalah sebagai edukator, manajer, administrator, leader, motivator dan supervisor madrasah. Tugas kepala madrasah sebagai supervisor 
diwujudkan dalam kemampuannya menyusun dan melaksanakan program supervisi pendidikan serta memamfaatkan hasilnya. Kemampuan menyusun program supervisi pedidikan harus dapat diwujudkan dalam penyusunan program perencanaan, pelaksanaan, evaluasi, serta tindak lanjut dari supervisi.

Supervisi dapat diartikan sebagai suatu aktivitas pembinaan yang direncanakan untuk membantu para guru dan pegawai madrasah dalam melakukan pekerjaan mereka secara efektif dan efisien (Depdiknas, 2003 dan Depag, 2000). Supervisi adalah aktivitas menentukan kondisi yang esensial yang akan menjamin tercapainya tujuan pendidikan. Maka tugas kepala madrasah sebagai supervisor berarti bahwa ia harus meneliti, mencari dan memberikan pengawasan dalam bentuk supervisi terhadap guru-guru bagi kemajuan madrasahnya. Menurut Syafriont (2011) supervisi adalah usaha dari petugas-petugas madrasah dalam memimpin guru-guru dan petugas-petugas lainnya, dalam memperbaiki pengajaran, termasuk menstimulir, menyeleksi pertumbuhan jabatan dan perkembangan guru-guru dan merevisi tujuan-tujuan pendidikan, bahan-bahan pengajaran dan metode mengajar dan evaluasi pengajaran.

Dalam konteks ini sebenarnya guru yang kurang kinerjanya sangat membutuhkan bimbingan dan arahan dari orang lain, atau supervisor dalam memecahkan masalah-masalah yang mereka hadapi untuk mencapai tujuan pendidikan. Sehingga peran guru yang sangat besar dalam meningkatkan mutu pendidikan dapat tercapai jika semua permasalahan yang dihadapi oleh guru dapat dipecahkan dengan baik.

Madrasah Ibtidaiyah Swasta (MIS) Singkarak merupakan suatu sekolah tingkat dasar yang berada di bawah naungan Kementerian Agama dengan proses pembelajaran lebih menitik beratkan pada pendidikan agama Islam. Seiring dengan perkembangannya saat ini MIS Singkarak telah memiliki Kepala Madrasah yang definitif (Chairul, S.Pd.) dengan 9 orang guru yang terdiri dari 3 PNS dan 6 honorer, dengan jumlah siswa 66 Orang (Studi Dokumen, 3 Januari 2016). Prestasi madrasah di tangan Bapak Chairul, S.Pd cukup banyak sekali di antaranya setiap tahun MIS Singkarak lulus 100\% dengan nilai yang baik, kemudian Bapak Chairul meraih peringkat I kepala SD/MI berprestasi tingkat Kecamatan X Koto Singkarak pada tahun 2013 dan meraih peringkat II Kepala SD/MI berprestasi tingkat Kabupaten Solok tahun 2013, meraih peringkat II Kepala SD/MI berprestasi Tingkat Kabupaten Solok tahun 2014.

Di samping prestasi yang diraih oleh Bapak Chairul, S.Pd sebagai kepala madrasah, guru-guru juga memiliki prestasi yng cukup baik di antaranya meraih peringkat III guru 
berprestasi Tingkat Kabupaten Solok tahun 2014. Selanjutya para siswa MIS Singkarak juga mempersembahkan berbagai prestasi di antaranya juara I lomba pramuka cabang pionering tingkat Kabupaten Solok tahun 2014, juara II lomba cipta puisi Tingkat Kecamatan X Koto Singkarak tahun 2014, juara I lomba Asmaul Husna Tingkat Kabupaten Solok tahun 2014, juara III lomba nyanyi religi tingkat Kabupaten Solok tahun 2014, juara III lomba futsal antar MI Kabupaten Solok tahun 2015 dan juara I lomba qasidah tingkat Kecamatan X Koto singkarak tahun 2015.

Dari paparan latar belakang di atas, menurut peneliti kajian supervisi akademik penting dilakukan di MIS Singkarak. Pentingnya aktifitas supervisi akademik MIS Singkarak berkaitan dengan peningkatan kualitas guru dan peningkatan mutu pendidikan.

\section{METODE PENELITIAN}

Penelitian ini merupakan penelitian kualitatif dengan metode deskriptif. Menurut Sukmadinata (2006) penelitian deskriptif merupakan penelitian yang berusaha mendeskripsikan dan mengintegrasikan sesuatu, misalnya kondisi atau hubungan yang ada, pendapat yang berkembang, proses yang sedang berlangsung, akibat atau efek yang terjadi, atau tentang kecenrungan yang tengah berlangsung. Sedangkan Menurut Furchan (2004) deskripsi adalah suatu bentuk wacana yang berusaha untuk melukiskan atau menggambarkan dengan kata-kata, wujud atau sifat lahiriah dari suatu obyek. Deskripsi merupakan salah satu tekhnik menulis menggunakan detail dengan tujuan membuat pembaca seakanakan berada di tempat kejadian itu, ikut merasakan, mengalami, melihat dan mendengar mengenai satu peristiwa atau adegan.

Dari pendapat di atas dapat peneliti simpulkan bahwa penelitian deskriptif merupakan penelitian yang menggambarkan serta memaparkan dengan kata-kata yang jelas dan terperinci dari hasil penelitian. Peneliti mengambil pelitian kualitatif dengan metode deskriptif ini adalah karena ingin mengungkap fakta dan gejala apa adanya serta menentukan dan menafsirkan data yang berkenaan dengan situasi yang terjadi di MIS Singkarak Kabupaten Solok dalam pelaksanaan supervisi akademik kepala madrasah dalam meningkatkan kinerja guru. Dalam mengumpulkan data yang dibutuhkan, peneliti menggunakan teknik pengumpulan data wawancara dan studi dokumen.

Teknik wawancara yang peneliti gunakan dalam pengumpulan data adalah teknik wawancara dengan bertanya langsung kepada 
responden. Menurut Nazir (1998) wawancara adalah proses memperoleh keterangan untuk tujuan penelitian dengan cara tanya jawab sambil bertatap muka antara si penanya atau pewawancara dengan si penjawab atau responden dengan menggunakan alat yang dinamakan interview guide (panduan wawancara). Adapun yang diwawancarai dalan penelitian ini adalah Kepala dan guru MIS Singkarak.

Studi dokumen adalah menelusuri surat penting atau surat berharga yang sifatnya tertulis atau tercetak yang berfungsi sebagai bukti atau keterangan. Menurut KBBI (2002) studi dokumen adalah pengumpulan, pemilihan, pengolahan dan menyimpan informasi di bidang pengetahauan, pemberian atau pengumpulan bukti dan keterangan seperti gambar, kliping, kutipan, dan bahan referensi lainnya. Dalam penelitian ini studi dokumen digunakan untuk menelusuri surat penting atau surat berharga, bukti atau keterangan terkait pelaksanaan supervisi akademik kepala madrasah.

\section{HASIL PENELITIAN DAN PEMBAHASAN}

Madrasah Ibtidaiyah Swasta (MIS) Singkarak telah melaksanakan supervisi pendidikan dengan baik berdasarkan perencanaan yang telah ditetapkan hal ini sebagaimana yang diungkapkan oleh Kepala
MIS Singkarak (Chairul, S.Pd.) melalui wawancara pada tanggal 26 Januari 2016 "dalam melaksanakan supervisi terhadap guru terlebih dahulu membuat program dari satu-satu guru persemester jadi setiap semester itu minimal satu orang guru mendapat satu atau dua kali supervisi (kunjungan kelas)”.

Dari penjelasan di atas dapat disimpulkan bahwa pada MIS Singkrak sebelum melaksanakan supervisi terlebih dahulu kepala madrasah membuat suatu perencaan supervisi mulai dari satu-satu guru persemester, sehingga semua guru dapat disupervisi dengan baik dalam usaha meningkatkan kerja guru tersebut. Dalam melaksanakan supervisi Kepala MIS menggunakan berbagai pendekatan atau metode, sebagaimana yang dijelaskan melalui wawancara dengan peneliti sebagai berikut "dalam pelaksanaan supervisi yang sudah dilaksanakan ada dua macam, yang pertama ada supervisi biasa yang sifatnya diskusi kemudian wawancara dengan guru-guru, kemudian supervisi klinis yang biasanya sudah terjadwal perkelas kapan dilaksanakan sesuai jadwal yang ditetapkan”.

Dari penjelasan tersebut dapat digambarkan bahwa dalam pelaksanaan supervisi pada MIS Singkarak menggunakan supervisi biasa, dengan melakukan berbagai bentuk kegiatan yang dapat membantu 
guru dalam mengatasi kesulitan-kesulitan yang dihadapi guru seperti melakukan diskusi, wawancara dengan guru hal ini tidak terjadwal namun ini terjadi secara mendadak atau di saat dibutuhkan oleh kepala maupun guru itu sendiri dalam memecahkan suatu persoalan. Kemudian yang kedua supervisi klinis hal ini dilakukan sesuai dengan jadwal yang telah ditetapkan oleh kepala madrasah sehingga guru-guru tidak terkejut di saat kepala madrasah masuk untuk melaksanakan supervisi tersebut.

Hal ini diperkuat oleh seorang guru Pendidikan Agama Isam (PAI) Syafniati (Hasil Wawancara, 26 Januari 2016) beliau mengatakan bahwa "metode yang dilakukan oleh Kepala Madrasah dalam pelaksanaan supervisi kadang-kadang metode secara langsung ke dalam kelas dan juga di luar kelas”. Bagi seorang guru, pengawasan dan supervisi dari atasan ini merupakan suatu yang sangat diharapkan sekali karena melalui supervisi akan dapat melihat sejauh mana kemampuan seseorang dalam melaksanakan tugas, sebagaimana hal ini dijelaskan oleh bapak Chairul (Hasil Wawancara, 26 Januari 2016) bahwa supervisi merupakan suatu hal yang wajib dilaksanakan. Hal ini juga diperkuat oleh salah seorang guru kelas yaitu Nurlifni (Hasil Wawancara, 26 Januari 2016) yang mengatakan bahwa "supervisi itu sangat baik untuk lebih memberikan motivasi bagi guru-guru dalam rangka melaksanakan tugas".

Hasil penelitian ini didukung oleh beberapa kajian terdahulu, pertama Syarif (2011) mengungkapkan bahwa komunikasi interpersonal kepala sekolah dan supervisi kepala sekolah berpengaruh positif dengan kinerja guru. Kemampuan komunikasi interpersonal dan supervisi kepala sekolah apabila mampu disinergikan akan memberi dampak positif terhadap kinerja guru. Kepala sekolah tidak hanya memberikan pengarahan dan pengawasan saja kepada guru, namun ia juga mampu mengkomunikasikan hal-hal yang penting guna menciptakan suasana kerja yang kondusif dan dinamis. Suasana yang demikian itu pada giliranya akan mampu mendorong semangat berkarya guru yang pada gilirannya dapat memacu kinerjanya.

Kedua, didukung oleh temuan penelitian yang dilakukan oleh Sudin (2008) bahwa pelaksanaan supervisi pembelajaran yang dilaksanakan di SD saat ini sebesar 45,27\% artinya pengawas dalam menjalankan tugasnya sebagai pembina dalam meningkatkan guru mata pelajaran masuk katagori cukup, baik pelaksanaan manajemen kelas, akademik, maupun pengembangan profesi guru. Komponen administratif berupa perencanaan pembelajaran selalu menjadi prioritas dalam melakukan pengawasan ke sekolah. 
Pembinaan yang diberikan terhadap guru SD sangat tidak jelas, karena pengawasannya kurang memahami apa yang seharusnya disupervisi. Kondisi ini semakin diperparah dengan latar belakang pengawas yang sama sekali tidak memahami materi (content) pembelajaran, sehingga guru SD tidak ada fasilitas yang dapat dijadikan tempat "curhat". Jadi, pelaksanaan supervisi pembelajaran saat ini di SD hanya bersifat administratif. Oleh karena itu, supaya supervisor dapat menjalankan tugasnya sebagai pengawas harus memiliki perencanaan terhadap tugas pokoknya.

Ketiga, didukung oleh temuan penelitian yang dilakukan oleh Subawa, dkk. (2015) menyimpulkan bahwa pelaksanaan supervisi akademik yang meliputi aspek tujuan, fungsi, teknik, pendekatan, prinsip-prinsip maupun materi ruang lingkup binaan supervisi itu jelas ada pengaruhnya terhadap kinerja guru. Karena kegiatan supervisi ini pada hakikatnya memberikan binaan kepada guru agar guru tersebut semakin berkualitas dan professional. Setiap pelaksanaan supervisi akademik tujuannya untuk mengukur performan guru sampai pada tingkat guru dapat melaksanakan tugas profesionalnya.

Melalui paparan pendapat di atas, dapat disimpulkan bahwa variabel supervisi akademik menentukan kinerja guru. Dengan demikian ada kaitan antara teori yang dijadikan landasan dalam pengujian hipotesis dengan hasil penelitian yang diperoleh. Dengan demikian, dugaan yang menyatakan ada kontribusi antara supervisi akademik guru dengan kinerja guru di SMP Negeri Kecamatan Gerokgak terbukti dalam penelitian ini adalah signifikan

Keempat, temuan Sudiana, dkk. (2015) mengungkapkan bahwa sesuai dengan tujuan, prinsip, dan kualitas supervisi akademik kepala sekolah yang antara lain bertujuan memberikan bantuan pada guru untuk mengatasi masalah pembelajaran yang dihadapi, di mana dalam pelaksanaan supervisi akademik tersebut, memperhatikan prinsip-prinsip dan kualitas supervisi maka akan terjadi perbaikan kualitas pembelajaran, sehingga terjadi peningkatan kualitas profesional guru dalam proses pembelajaran.

Di samping sebagai seorang pemimpin, kepala sekolah juga seorang supervisor yang harus dapat melaksanakan tugas tersebut dengan baik. Supervisi dirumuskan sebagai proses perbaikan, peningkatan kelas dan sekolah melalui kerja sama secara langsung dengan guru. Untuk itu supervisi perlu memilih kegiatan supervisinya sesuai dengan tujuan perbaikan atau peningkatan pembelajaran tertentu. Pemilihan kegiatan supervisi yang bersumber dari pandangan mendasar itu, menjadikan supervisi lebih kokoh karena memiliki pijakan ilmiah dan lebih efektif. 
Diketahui bahwa kualitas profesional guru berbeda-beda dan memiliki karakteristik yang heterogen sehingga penerapan pendekatan supervisi harus bervariasi. Keberhasilan kepala sekolah dalam melaksanakan supervisi tergantung dari pendekatan yang digunakan. Guru yang memiliki kemampuan tinggi cenderung tidak memerlukan pembinaan secara mendetail, sedangkan guru yang memiliki kemampuan rendah, lebih banyak memerlukan bimbingan. Setelah mendapat supervisi kepala sekolah, guru akan mengalami peningkatan kualitas profesionalnya.

Dari paparan tersebut terdapat pengaruh antara supervisi akademik kepala sekolah terhadap kualitas profesional guru. Dalam pengertian semakin baik supervisi kepala sekolah maka semakin tinggi kualitas profesional guru dalam melaksanakan tugasnya.

Kelima temuan Nyoman, dkk. (2015) menyimpulkan bahwa supervisi pengawas sekolah ini didefinisikan secara operasional sebagai intensitas pelaksanaan tugas-tugas supervisi yang dilakukan pengawas terhadap tugas profesional guru yang mencakup pembinaan, penilaian, dan pengukuran keberhasilan guru. Sebagai indikator untuk masing-masing aspek tersebut adalah (1) merencanakan dan melaksanakan supervisi, bimbingan membuat perangkat pembelajaran, memberikan arahan/contoh dalam pelaksanaan pembelajaran, kesediaan sebagai partner kerja, menciptakan suasana kondusif, bantuan dalam memahami kurikulum, memberikan motivasi kenaikan pangkat para guru, memberikan motivasi untuk mengembangkan profesi, memberikan bantuan dalam mengidentifikasikan masalah pembelajaran, memberikan bimbingan dalam menentukan langkah-langkah untuk mengatasi masalah dalam pembelajaran; dan (2) melaksanakan penilaian terhadap kegiatan belajar mengajar, melaksanakan tindak lanjut hasil penilaian. Untuk mengukur pelaksanaan pengawasan dalam supervisi pengajaran dilakukan dengan menggunakan kuesioner supervisi pengawas sekolah yang dikembangkan sendiri berdasarkan teori yang digunakan.

\section{KESIMPULAN}

Berdasarkan paparan di atas, Madrasah Ibtidaiyah Swasta (MIS) Singkarak telah melaksanakan supervisi pendidikan dengan baik berdasarkan perencanaan yang telah ditetapkan. Dalam pelaksanaan supervisi Kepala MIS Singkarak menggunakan supervisi biasa, dengan melakukan berbagai bentuk kegiatan yang dapat membantu guru dalam mengatasi kesulitan-kesulitan yang dihadapi guru seperti melakukan diskusi, wawancara dengan guru hal ini tidak terjadwal namun ini terjadi secara mendadak atau di saat dibutuhkan. Kemudian Kepala 
MIS Singkarak juga melakukan supervisi klinis, hal ini dilakukan sesuai dengan jadwal yang telah ditetapkan oleh kepala madrasah sehingga guru-guru tidak terkejut di saat kepala madrasah masuk untuk melaksanakan supervisi tersebut.

Supervisi sangat penting dilakukan oleh seorang kepala sekolah dalam rangka meningkatkan kulitas kerja seorang guru, karena tidak mungkin sesuatu hal akan jadi lebih baik kalau tidak diberi arahan. Kepala sekolah/madrasah yang merupakan seorang supervisor wajib melaksanakan supervisi karena supervisi di sebuah madrasah merupakan tanggungjawabnya, oleh karena itu seorang kepala harus memahami dan menguasasi tugas dan tanggung jawab supervisi.

\section{KEPUSTAKAAN ACUAN}

Danim, S. (2002). Inovasi Pendidikan. Bandung: CV. Pustaka Setia.

Depag. (2000). Pedoman Pelaksanaan Supervisi Pendidikan. Jakarta: Departemen Agama.

Depdiknas. (2003). Supervisi Pendidikan. Jakarta: Direktorat Jenderal Pendidikan Dasar dan Menengah.

Furchan, Ahmad. (2004). Pengantar Penelitian dalam Pendidikan. Yogyakarta: Pustaka Belajar
KBBI. (2002). Kamus Besar Bahasa Indonesia. Jakarta: Balai Pustaka.

Nazir, Muhammad. (1988). Metode Penelitian. Jakarta: Ghalia Indonesia.

Nyoman, Wida. Natajaya, I Nyoman. dan Anak Agung Gede Agung. (2015). Supervisi Pengawas Sekolah terhadap Tugas Profesional Guru. Jakarta: Universitas Negeri Jakarta.

Pidarta, Made. (2006). Landasan Kependidikan. Jakarta: Rineka Cipta.

Subawa, I Made. Agung, Anak Agung Gede. I Made Yudana. (2015). Pelaksanaan Supervisi Akademik SMP Negeri Kecamatan Gerokgak. Jakarta: Universitas Negeri Jakarta

Sudiana, Nyoman. Agung, Anak Agung Gede. dan I Made Yudana. (2015). Tujuan, Prinsip, dan Kualitas Supervisi Akademik Kepala Sekolah. Jakarta: Universitas Negeri Jakarta.

Sudin, Ali. (2008). Pelaksanaan Supervisi Pembelajaran di SD Kota Padang. Padang: Universitas Negeri Padang.

Sukmadinata. (2006). Metode Penelitian Pendidikan. Bandung: Remaja Rosdakarya. 
Sulistyorini. (2001). Hubungan antara Keterampilan Manajerial Kepala Sekolah dan Iklim Organisasi dengan Kinerja Guru. Ilmu Pendidikan

Syafriont. (2011). Model Pembinaan dan Supervisi Pendidikan. Malang: Timple, A. Dale. (1992). Kinerja. Jakarta : Universitas Negeri Malang.
Syarif, Maryadi. (2011). Pengaruh Komunikasi Interpersonal Kepala Sekolah dan Supervisi Kepala Sekolah Terhadap Kinerja Guru. Padang: Universitas Negeri Padang PT. Gramedia Asri Media. 